IZA DP No. 9126

Children's Media Use and Homework Time

Sabrina Wulff Pabilonia

June 2015 


\title{
Children's Media Use and Homework Time
}

\author{
Sabrina Wulff Pabilonia \\ U.S. Bureau of Labor Statistics \\ and IZA
}
Discussion Paper No. 9126
June 2015

IZA
P.O. Box 7240
53072 Bonn
Germany

Phone: +49-228-3894-0

Fax: +49-228-3894-180

E-mail: iza@iza.org

Any opinions expressed here are those of the author(s) and not those of IZA. Research published in this series may include views on policy, but the institute itself takes no institutional policy positions. The IZA research network is committed to the IZA Guiding Principles of Research Integrity.

The Institute for the Study of Labor (IZA) in Bonn is a local and virtual international research center and a place of communication between science, politics and business. IZA is an independent nonprofit organization supported by Deutsche Post Foundation. The center is associated with the University of Bonn and offers a stimulating research environment through its international network, workshops and conferences, data service, project support, research visits and doctoral program. IZA engages in (i) original and internationally competitive research in all fields of labor economics, (ii) development of policy concepts, and (iii) dissemination of research results and concepts to the interested public.

IZA Discussion Papers often represent preliminary work and are circulated to encourage discussion. Citation of such a paper should account for its provisional character. A revised version may be available directly from the author. 
IZA Discussion Paper No. 9126

June 2015

\section{ABSTRACT}

\section{Children's Media Use and Homework Time*}

Homework is an important part of the academic production function, but often students are studying while doing another activity. Using the nationally representative Panel Study of Income Dynamics-Child Development Supplement time diaries, this chapter explores changes over the period 1997-2008 in homework time for U.S. children in $1^{\text {st }}$ through $12^{\text {th }}$ grade when homework is done as a sole activity versus simultaneously with another activity. It documents with which technologies and media homework is done simultaneously and how the share of multitasking time differs by gender. This chapter also examines the correlation between childhood attention difficulties and multitasking while studying.

JEL Classification: J24

Keywords: multitasking, homework, human capital

Corresponding author:

Sabrina Wulff Pabilonia

U.S. Bureau of Labor Statistics

2 Massachusetts Ave. NE, Rm. 2180

Washington, DC 20212

USA

E-mail: Pabilonia.Sabrina@bls.gov

\footnotetext{
* All views expressed in this paper are those of the author and do not necessarily reflect the views or policies of the U.S. Bureau of Labor Statistics.
} 


\section{Introduction}

Homework is an important component of the academic production function (Aksoy and Link, 2000; Betts, 1997; Eren and Henderson, 2008, 2011), but often students are studying while doing another activity. Over the last decade, children have had increasing access to many types of media outlets that may distract their attention. The number of televisions and personal computers per household has grown; the growth of broadband access has increased computing potential on home computers, mobile phones, and other devices; and the options for devices on which to listen to music as well as the access to different types of music has expanded. Previous research has found that proximity to devices, such as placement of a computer near a television, is a strong predictor of media multitasking (Foehr, 2006). Using U.K. time use data, Kenyon (2008) has shown that the internet has changed how we use our time - both in the activities we choose and in the extent that we are multitasking.

Dividing their attention between homework and another activity, such as a media-related activity, may have significant negative consequences for students’ academic success. For example, a paper by Rosen, Carrier, and Cheever (2013) found that those who used Facebook while doing homework had lower grade point averages. A study by Pool, Koolstra and van der Voort (2003) found that students performed more poorly on two types of homework assignments if they simultaneously watched a soap opera but not if music was playing in the background while they worked. Patton, Stinard, and Routh (1983) noted that students considered the TV a moderate distracter but music as beneficial. However, research has been inconclusive as to whether academic performance is enhanced with background pop or rock music, which is the genre preferred by most students (Adriano and DiPaola 2010). The type of assignment, for example math or reading, may influence whether multitasking has a negative effect on 
performance, for example if music is a distraction from reading passages but not from doing math (Adriano and DiPaola 2010).

This chapter uses detailed time-diary data from 1997 to 2008 to examine the growth in multitasking while doing homework among U.S. schoolchildren as electronic media use has expanded, with a focus on how multitasking differs by gender and school level. Previous research (Adriano and DiPaola, 2010) has found that girls were more likely to listen to music while completing math homework than were boys, indicating possible differences by gender in multitasking levels and/or effects. ${ }^{1}$ I perform analyses separately by school level because the amount of homework assigned typically increases with each grade level. Students also typically experience less parental supervision as they grow older. I document which types of activities frequently are done simultaneously with homework and how much homework is done on the computer. Finally, I examine which individual and family characteristics influence students' ability or desire to multitask. I pay particular attention to characteristics that may increase students' access to electronic media. I also examine whether children who are reported by their parents to have attention issues are more likely to do other activities while doing their homework than children not so described. Children with ADHD who often are characterized by their inability to stay on task in school and their difficulty paying attention are more likely to have poorer educational outcomes (Currie and Stabile, 2006; Fletcher and Wolfe, 2008). One mechanism that has yet to be explored through which this health condition could affect human capital accumulation is their ability to stay on task during homework time.

\section{Data and Descriptive Statistics}


This chapter uses the nationally-representative Panel Study of Income Dynamics-Child Development Supplement (PSID-CDS) time diaries to explore changes in homework time for U.S. children in 1st through 12th grade over the period 1997-2008 when homework is done as a sole activity versus simultaneously with another activity. The PSID-CDS is a longitudinal survey of children aged 0-10 in 1997. Up to two children per family were interviewed in 1997, with follow-up surveys approximately 5 and 10 years later in the 2002-2003 and 2007-2008 school years. In addition to detailed surveys from caregivers (usually parents), children, and teachers, two 24-hour time diaries were completed for each selected child per wave, one for a weekday and the other for a weekend day. A caregiver or child filled out the diaries, listing primary and secondary activities occurring from midnight to midnight on each diary day. Most high school students filled out their own time diaries. The listing of secondary activities is a rather unique feature of the survey that allows one to measure the multitasking of activities using survey data. During the primary caregiver interview, the respondent was asked to decide whether it was often true, sometimes true, or not true that the target child had difficulty concentrating or that the child could not pay attention for a long time. In order to examine the correlation between attention issues and multitasking, I create an indicator equal to one if a caregiver reported that it was often true that a child could not pay attention for a long time and zero otherwise. This chapter also uses additional information on family structure and parental education from the main PSID survey.

The sample is limited to students who completed both a weekday and a weekend day diary, who did not complete their time diaries over winter break or on any day in June when they did not attend school, who were not missing information on race, whose family income was not negative, who were not missing information on family structure, and who were not missing a 
child interview in 2007. Those respondents who did not have a child interview in 2007 had no child weight assigned. The analysis samples include 1,873 elementary school students, 1,017 middle school students, and 1,249 high school students, where elementary school students are in grades $1-5$, middle school students are in grades $6-8$, and high school students are in grades 912. See the Appendix Tables A1-A3 for further details of the sample construction for each set of students. Appendix Table A4 shows that each survey year has approximately the same grade level distribution; thus, it is possible to make comparisons over time. All of the analyses use CDS child weights.

I begin by analyzing students’ participation in homework activities occurring outside the classroom separately by gender and survey year. Each measure of homework is a weekly measure that was constructed by multiplying the weekday time spent by 5 and the weekend day time spent by 2, and then adding these two products together, as in Hofferth (2010). Homework time includes all time outside of class when the student reports either using a computer for homework, being tutored, doing general homework, studying, doing research, reading related to classes, working on a school project, going to the library, or reviewing homework with a parent. I create three main measures of homework time: total homework time, homework as a sole activity, and multitasking while doing homework. Total homework time captures the sum of all homework done regardless of whether a secondary activity was reported. Homework could have been reported as the secondary activity, with another activity reported as the primary activity. Previous studies suggest that not all individuals may be able to distinguish their primary activity from their secondary activity (Robinson and Godbey, 1997). Homework as a sole activity is time when homework is reported as the primary activity and no secondary activity is reported. Finally, multitasking while doing homework is when two activities are reported and one of the 
activities is homework. I also document how much time students spend using the computer to do their homework. The time that students spend using the computer for the sole purpose of doing homework is included in the time spent on homework as a sole activity if the student reports only one activity. I then construct five measures of homework done simultaneously with other activities. The activities most frequently done with homework by high school students include listening to music, watching TV, talking with others in person or on the phone (subsequently referred to as "talking”), using the computer or mobile phone but not for homework (subsequently referred to as “computer”), and eating, in decreasing order of time spent on each. Using the computer for non-homework activities includes communication with others via social media or e-mail, playing computer games, or surfing the web. Younger students have slightly different frequencies for concurrent activities with homework time than do older students. For example, they spend almost no time using a computer while doing their homework.

Table 1 presents the average weekly hours spent on homework and multitasking activities, the percentage of students doing any homework over the two diary days, and the percentage of those doing any homework who do their homework simultaneously with another activity for each school level by gender. Not surprisingly, the amount of time students spent on homework increased monotonically in any given school year as the school level increased. There were also increases in doing homework over time at the elementary school level. Elementary school students were more likely to be doing some homework during the 2002-2003 school year than during the 1997-1998 school year, and female students were more likely to be doing more homework during the 2002-2003 school year than during the 1997-1998 school year. However, elementary school girls and boys, on average, spent similar amounts of time per week on total homework. As students entered higher grades, more apparent gender differences 
emerged in time spent on homework. Middle school girls were about 10 percentage points more likely to be doing any homework during the 2007-2008 school year than were middle school boys (71 percent versus 61 percent). Middle school boys studied both less often and fewer hours overall during the 2007-2008 school year than the 2002-2003 school year.

In the 2002-2003 school year, there were quite dramatic gender differences in both the likelihood of spending any time on homework and the amount of time spent on homework for high school students. In the 2002-2003 school year, 72 percent of high school girls reported doing homework while only 52 percent of high school boys reported doing homework. High school girls spent nearly 4 hours more time studying per week than high school boys during the 2002-2003 school year (8.25 hours versus 4.39 hours). There was also a decrease in the amount of homework girls did in high school over time (8.25 hours versus 6 hours) and a small increase over time in the likelihood of doing any homework by boys (52 percent versus 61 percent).

There were significant gender differences in multitasking while doing homework for elementary and high school students in the 2002-2003 school year, with girls more likely than boys to be doing their homework while also doing another activity (53 percent versus 31 percent in elementary school and 60 percent versus 32 percent in high school). In the 2007-2008 school year, middle school girls were also more likely to be multitasking while doing homework than were middle school boys (53 percent versus 31 percent). High school boys during the 20072008 school year were much more likely to be multitasking while doing homework than were high schools boys during the 2002-2003 school year (52 percent versus 32 percent).

Elementary school students spent about one-third of their homework time doing other activities simultaneously. This translates to roughly one hour of multitasked homework time per week, given that these students spent 3 hours per week on homework in total on average. For 
elementary school students, the activity done most frequently with homework was talking with others, either in person or on the phone. For female students, the amount of time spent doing these activities jointly increased significantly between the 1997-1998 and 2002-2003 school years ( 0.41 hours versus 0.71 hours). However, it is not clear that homework time and talking with others would have negative academic consequences, especially for younger children, who may be receiving homework help from a parent, at least intermittently. Elementary school students spent very little time doing their homework on a computer.

During the 2002-2003 school year, 48 percent of middle school girls were multitasking while doing homework, and 33 percent of middle school girls' homework time was spent doing other activities simultaneously. By the 2007-2008 school year, 53 percent of middle school girls were multitasking while doing homework, and 39 percent of middle school girls' homework time was spent doing other activities simultaneously. The activity done most frequently with homework by middle school girls was watching TV in 2002-2003 but listening to music in 2007-2008. Between the 2002-2003 and 2007-2008 school years, middle school girls saw an increase in eating while doing homework ( 0.03 hours versus 0.19 hours).

During the 2002-2003 school year, 41 percent of middle school boys were multitasking while doing homework, and 29 percent of middle school boys' homework time was spent doing other activities simultaneously. By the 2007-2008 school year, only 31 percent of middle school boys were multitasking while doing homework, but 35 percent of middle school boys' homework time was spent doing other activities simultaneously. The activity done most frequently with homework was talking with others in 2002-2003 but watching TV in 20072008. The later middle school student cohort spent more time doing their homework on a computer than did the earlier cohort. 
Except for male high school students in 2002-2003, high school students were more likely to be multitasking while doing homework than were students in lower grades. During the 2002-2003 school year, high school girls spent 48 percent of their homework time doing other activities simultaneously. By the 2007-2008 school year, they spent 56 percent of their homework time doing other activities simultaneously. The activity done most frequently with homework was listening to music; watching TV was the second activity most frequently done with homework. The earlier cohort (2002-2003) of high school boys spent 32 percent of their homework time doing other activities simultaneously with homework, but the later cohort (2007-2008) of boys spent 59 percent of their homework time doing other activities simultaneously with homework. The activity most frequently done with homework by high school boys was listening to music for the 2002-2003 cohort and watching TV for the 2007-2008 cohort; talking with others was the second activity most frequently done with homework for the 2002-2003 cohort, and listening to music was the second activity most frequently done with homework for the 2007-2008 cohort.

High school students spent more time using computers and mobile phones for pleasure while doing homework than did younger students, with later cohorts spending more time simultaneously doing these two activities than did earlier cohorts. In 2007-2008, girls spent about half an hour per week using the computer while doing homework, and boys spent nearly a quarter of an hour per week using the computer while doing homework. In over 75 percent of the diary episodes for these joint activities, students were using a mobile phone or computer to communicate with others as a secondary activity. Over time, we also see that the later high school student cohort spent more time doing their homework on a computer than did the earlier cohort (over an hour versus less than a half an hour). 
In summary, I find that elementary-school students in the later cohort were spending more time doing homework than students in the earlier cohort and were spending more time multitasking while doing homework. High-school and middle-school girls were spending more time doing homework than high-school and middle-school boys were spending. They were also more likely to be multitasking while doing homework. Given that experimental research by Bowman et al. (2010) found that students took longer to read a passage of text online if they were simultaneously instant messaging, one possible explanation for why high school girls, especially those in the earlier cohort, spent longer on homework is that they spent more time multitasking with TV and computers for personal pleasure than did boys. Thus, longer time spent on homework may not necessarily translate into a greater quantity of homework completed or higher quality homework.

\section{Determinants of Multitasking While Doing Homework}

I next examine who is multitasking among those doing homework, using the following probit model:

$$
\operatorname{Pr}(\mathrm{Y}=1)=\mathrm{F}\left(\mathrm{a}_{0}+\mathrm{a}_{1} \mathrm{X}\right)
$$

where the dependent variable, $\mathrm{Y}$, takes the value of one if the student is multitasking while doing homework and zero otherwise; $\mathrm{X}$ is the vector of control variables; $\mathrm{a}_{0}$ and $\mathrm{a}_{1}$ are the coefficients to be estimated; and F(.) is the CDF of the standard normal distribution. The subscripts indicating observation are suppressed. $\mathrm{X}$ includes a rich set of individual-level and family-level controls. The individual-level controls include indicators for being female, being black or Hispanic, age-adjusted broad-reading and applied-problems standardized test scores from the Woodcock-Johnson Revised Tests of Basic Achievement (WJ-R), whether the primary caregiver 
reported that the student often had trouble paying attention, the Census region of residence, season of diary, grade in school, and survey year. ${ }^{2}$ The family-level controls include the number of computers in the home, the number of other household children under age 20, the average real family income over the five years prior to the time diary and its square, and indicators for whether the mother has a college degree, whether mother's degree is missing, whether the child lives with a single mother, whether the child lives in some other family arrangement than a twoparent family, and whether the family has internet access in the home. ${ }^{3}$ These controls are intended to absorb various sources of influence on homework time and homework multitasking behavior, including those related to children's access to technology and parental influence and involvement in homework.

Tables 2-4 present the average marginal effects calculated from the estimation results of the probit model of homework multitasking shown in equation (1) by school level and gender. ${ }^{4}$ Robust standard errors are adjusted for clustering by household. Male high school students and elementary students who have a higher reading ability are more likely to be multitasking while doing homework. Female middle school students who have a higher reading ability are less likely to be multitasking while doing homework, but those with a higher math ability are more likely to be multitasking while doing homework. High school students living in the West are more likely to be multitasking while doing homework than those living in the Northeast. Male middle school students are more likely to be multitasking in the winter months than the spring months. Male high school students whose mothers have college degrees are more likely to be multitasking than those whose mothers do not have degrees. They are less likely to be multitasking with homework if there are more children in the household, perhaps due to lack of access to shared household electronic devices. Male middle school students who have internet 
access in their home are also more likely to be multitasking, consistent with prior research by Foehr (2006). These latter three findings suggest that access to electronic media is an important predictor of whether a male student will be multitasking while doing homework. Female high school students were more likely to be multitasking during the 2002-2003 school year than the 2007-2008 school year. Finally, I find that attention issues are positively correlated with the probability of multitasking among female high school students. Thus, those who have difficulty paying attention are more likely to do another task while they are doing homework.

\section{Conclusion}

Using time-diary data from the PSID-CDS, this chapter documents how prevalent multitasking has become while doing homework, especially among high school students. High school girls spend more time doing homework and more of that homework time doing simultaneous activities than do boys. One possible explanation for the longer time that is reported to be spent on homework by girls is that much of that time was spent alternating their attention between their studies and another activity, such as watching TV. I also find that students are increasingly using the computer both for homework purposes and for other activities while doing homework.

Using a probit model, I also examine the determinants of multitasking while doing homework. The findings are mixed on the relationship between ability test scores and multitasking while doing homework, with evidence suggesting that males with higher reading ability scores are more likely to multitask while doing homework but females with higher reading ability scores are less likely to multitask while doing homework. However, females with higher math ability scores were more likely to be multitasking while doing homework. I also 
find evidence that female high school students whose parents reported that the students have difficulty paying attention are more likely to be multitasking while doing homework. Finally, the availability of technology in the household increases the likelihood that a male student is multitasking while doing homework.

This divided attention between homework and other activities, especially electronic media activities such as watching TV or using computers for leisure purposes, may have negative consequences for students' academic success. Multitasking while doing homework could also potentially distract the student away from other human-capital enhancing activities or health-promoting activities, such as exercise, if it increases the total amount of time devoted to homework activities. Additional research using longitudinal data on both time use and outcomes could help us to better understand how multitasking while studying affects human capital accumulation, long-term academic outcomes, and health outcomes.

1. Prior research on the multitasking of housework activities has shown that women are more likely than men to multitask (e.g. Offer and Schneider, 2011; Zaiceva and Zimmerman, 2011). 2. I also include an indicator variable for missing ability test scores and assign the average test score to those missing scores. For high school students, these test scores are from the CDS interview occurring five years prior to the high school interview, because test scores earlier in life may be a better measure of inherent ability than tests administered during high school. 3. Two-parent families included biological, adoptive, or step parents. The number of computers and internet access is not available in the 1997 interview and thus omitted from the elementary school student analyses.

4. The reference category for the elementary-school student regressions (Table 2) includes white students in Grade 5 in public school living in the eastern Census region with two parents whose mothers do not have a college degree who are interviewed in the spring of the 2007-2008 school year and who have no attention issue. The reference category for the middle-school student regressions (Table 3) includes white students in Grade 6 in public school living in the eastern Census region with two parents whose mothers do not have a college degree who are interviewed in the spring of the 2007-2008 school year and who have no attention issue. The reference category for the high-school student regressions (Table 4) includes white students in Grade 12 in public school living in the eastern Census region with two parents whose mothers do not have a college degree who are interviewed in the spring of the 2007-2008 school year and who have no attention issue. 


\section{References}

Adriano, Jennifer, and Thomas DiPaola. (2010). “Teenagers’ Reasons for Listening to Music and the Students' Perception of the Effects of Listening When Completing School Assignments.” Paper presented at the 42nd annual meeting of the New England Educational Research Organization, April, 2010, Portsmouth, NH.

Aksoy, Tevfik, and Charles R. Link. (2000). “A Panel Analysis of Student Math Achievement in the U.S. in the 1990s: Does Increasing the Amount of Time Learning Activities Affect Math Achievement?” Economics of Education Review 19: 261-277.

Betts, Julian R. (1997). “The Role of Homework in Improving School Quality.” Unpublished Manuscript. Department of Economics, University of California, San Diego.

Bowman, Laura L., Laura E. Levine, Bradley M. Waite, and Michael Gendron. (2010). “Can Students Really Multitask? An Experimental Study of Instant Messaging While Reading.” Computers \& Education 54: 927-31.

Currie, Janet, and Mark Stabile. (2006). "Child Mental Health and Human Capital Accumulation: The Case of ADHD.” Journal of Health Economics 25: 6. 1094-1118.

Eren, Ozkan, and Daniel J. Henderson. (2008). “The Impact of Homework on Student Achievement.” Econometrics Journal 11: 326-348.

Eren, Ozkan, and Daniel J. Henderson. (2011). “Are We Wasting our Children’s Time by Giving Them More Homework?” Economics of Education Review 30: 950-961.

Fletcher, Jason and Barbara Wolfe. (2008). "Child Mental Health and Human Capital Accumulation: The Case of ADHD Revisited.” Journal of Health Economics 27 (3):794-800.

Foehr, Ulla G. (2006). “Media Multitasking Among American Youth: Prevalence, Predictors, and Pairings.” The Henry J. Kaiser Family Foundation.

Hofferth, Sandra L. (2010). “Home Media and Children’s Achievement and Behavior.” Child Development 81(5): 1598-1619.

Kenyon, Susan. (2008). “Internet Use and Time Use: The Importance of Multitasking.” Tine \& Society 17, 2-3: 283-318.

Offer, Shira and Barbara Schneider. (2011) "Revisiting the Gender Gap in Time-Use Patterns: Multitasking and Well-Being Among Mothers and Fathers in Dual-earner Families.” American Sociological Review 76(6): 809-833.

Patton, James E., Thomas A. Stinard, and Donald K. Routh. (1983). "Where Do Children Study?” Journal of Educational Research 76(5): 280-286. 
Pool, Marina M., Cees M. Koostra, and Tom H.A. van der Voort. (2003). “The Impact of Background Radio and Television on High School Students' Homework Performance.” Journal of Communication 53(1): 74-87.

Robinson, John, and Geoffrey Godbey. (1997) Time for Life: The Surprising Ways Americans Use Their Time. University Park, Pa: Pennsylvania State University Press.

Rosen, Larry D., L. Mark Carrier, and Nancy A. Cheever. (2013). "Facebook and Texting Made Me Do It: Media-induced Task-Switching While Studying.” Computers in Human Behavior 29: 948-958.

Zaiceva, Anzelika, and Zimmermann, Klaus F. (2011). “Do Ethnic Minorities `Stretch’ Their Time? UK Household Evidence on Multitasking." Review of Economics of the Household 9: 181-206. 


\begin{tabular}{|c|c|c|c|c|}
\hline & \multicolumn{4}{|c|}{ Elementary School } \\
\hline & \multicolumn{2}{|c|}{ 1997-1998 } & \multicolumn{2}{|c|}{ 2002-2003 } \\
\hline \% doing any homework & $0.60 \dagger \dagger$ & $0.64 \dagger$ & $0.69 \dagger \dagger$ & $0.70 \dagger$ \\
\hline \multicolumn{5}{|l|}{ Hours per week per activity } \\
\hline Total homework & $2.83 \dagger \dagger$ & 3.18 & $3.51 \dagger \dagger$ & 3.28 \\
\hline Homework as a sole activity & 1.84 & 2.17 & 2.08 & 2.19 \\
\hline Homework and music & 0.02 & 0.00 & 0.07 & 0.01 \\
\hline Homework and TV & 0.10 & 0.13 & 0.11 & 0.08 \\
\hline Homework and talking & $0.41 \dagger \dagger$ & 0.49 & $0.71 \dagger \dagger$ & 0.70 \\
\hline Homework and computers & 0.00 & 0.01 & 0.00 & 0.00 \\
\hline Homework and eating & 0.15 & 0.09 & 0.16 & 0.13 \\
\hline
\end{tabular}

Notes: CDS child weights used. Statistical significance for gender differences: ${ }^{* * *} \mathrm{p}<0.01$; ${ }^{* *} \mathrm{p}<0.05$; ${ }^{*} \mathrm{p}<0.10$. Statistical significance over time: $† \dagger \dagger \mathrm{p}<0.01$; †† $\mathrm{p}<0.05$; † $\mathrm{p}<0.10$. 


\begin{tabular}{|c|c|c|c|c|c|c|c|c|}
\hline & \multicolumn{4}{|c|}{ Middle School } & \multicolumn{4}{|c|}{ High School } \\
\hline & \multicolumn{2}{|c|}{$\underline{2002-2003}$} & \multicolumn{2}{|c|}{$\underline{\text { 2007-2008 }}$} & \multicolumn{2}{|c|}{$\underline{2002-2003}$} & \multicolumn{2}{|c|}{$\underline{2007-2008}$} \\
\hline & Female & Male & Female & Male & Female & Male & Female & Male \\
\hline \% doing any homework & 0.67 & $0.70 \dagger$ & $0.71^{*}$ & $0.61 * \dagger$ & $0.72 * * *$ & $0.52 * * * \dagger$ & 0.66 & $0.61 \dagger$ \\
\hline \% multitasking while doing homework & 0.48 & 0.41 & $0.53 * * *$ & $0.31 * * *$ & $0.60 * * *$ & $0.32 * * * \dagger \dagger \dagger$ & 0.58 & $0.52 \dagger \dagger \dagger$ \\
\hline \multicolumn{9}{|l|}{ Hours per week spent on each activity } \\
\hline Total homework & 5.67 & $5.03 \dagger$ & 4.61 & $3.97 \dagger$ & $8.25 * * * \dagger \dagger \dagger$ & $4.39 * * *$ & $6.00 \dagger \dagger \dagger$ & 5.45 \\
\hline Homework as a sole activity & 3.71 & $3.55 \dagger \dagger$ & 2.78 & $2.57 \dagger \dagger$ & $4.26 * * \dagger \dagger \dagger$ & $3.00 * *$ & 2.63 & 2.37 \\
\hline Multitasking with homework & 1.96 & 1.48 & 1.82 & 1.39 & $3.99 * * *$ & $1.39 * * * \dagger \dagger \dagger$ & 3.37 & $3.08 \dagger \dagger \dagger$ \\
\hline \multicolumn{9}{|l|}{ Frequent simultaneous activities } \\
\hline Homework and music & 0.38 & 0.15 & 0.56 & 0.33 & $1.39 * *$ & $0.63^{* *}$ & 0.99 & 0.79 \\
\hline Homework and TV & 0.54 & 0.40 & 0.31 & 0.57 & $1.16^{* * *}$ & $0.19 * * * \dagger \dagger$ & 0.87 & $1.28 \dagger \dagger$ \\
\hline Homework and talking & 0.44 & 0.42 & 0.30 & 0.39 & 0.52 & 0.32 & 0.33 & 0.48 \\
\hline Homework and computers & 0.04 & 0.03 & 0.02 & 0.01 & $0.24 * * \dagger$ & $0.02 * * \dagger \dagger$ & $0.53 * \dagger$ & $0.22 * \dagger \dagger$ \\
\hline Homework and eating & $0.03 \dagger$ & 0.07 & $0.19 * * \dagger$ & $0.02 * *$ & 0.23 & 0.15 & 0.28 & 0.15 \\
\hline Using computer for homework & $0.24 \dagger \dagger$ & $0.15 \dagger \dagger$ & $0.72 \dagger \dagger$ & $0.51 \dagger \dagger$ & $0.46 \dagger \dagger \dagger$ & $0.15 \dagger \dagger \dagger$ & $1.19 \dagger \dagger \dagger$ & $1.48 \dagger \dagger \dagger$ \\
\hline Number of observations & 266 & 231 & 265 & 255 & 318 & 296 & 310 & 325 \\
\hline
\end{tabular}




\begin{tabular}{|l|c|c|}
\hline \multicolumn{3}{|l}{ Table 2. Multitasking Among Elementary School Students Who do Homework by Gender } \\
(Probit Model Marginal Effects)
\end{tabular}




\begin{tabular}{|c|c|c|}
\hline Independent variables & Female & Male \\
\hline \multirow[t]{2}{*}{ WJ-R broad reading test score } & $-0.006 * *$ & 0.001 \\
\hline & $(0.003)$ & $(0.003)$ \\
\hline \multirow[t]{2}{*}{ WJ-R applied problems test score } & $0.006^{* *}$ & 0.001 \\
\hline & $(0.003)$ & $(0.003)$ \\
\hline \multirow[t]{2}{*}{ Test score missing } & 0.055 & -0.124 \\
\hline & $(0.087)$ & $(0.083)$ \\
\hline \multirow[t]{2}{*}{ Private school } & 0.030 & -0.048 \\
\hline & (0.113) & $(0.113)$ \\
\hline \multirow[t]{2}{*}{ Midwest } & 0.079 & 0.045 \\
\hline & $(0.105)$ & $(0.105)$ \\
\hline \multirow[t]{2}{*}{ South } & 0.078 & 0.102 \\
\hline & $(0.109)$ & $(0.104)$ \\
\hline \multirow[t]{2}{*}{ West } & 0.043 & 0.143 \\
\hline & (0.111) & $(0.106)$ \\
\hline \multirow[t]{2}{*}{ Number of household children under age 20} & -0.007 & -0.040 \\
\hline & $(0.027)$ & $(0.034)$ \\
\hline \multirow[t]{2}{*}{ Household income } & 0.002 & 0.000 \\
\hline & $(0.001)$ & $(0.001)$ \\
\hline \multirow[t]{2}{*}{ Household income squared } & $-0.000^{*}$ & 0.000 \\
\hline & $(0.000)$ & $(0.000)$ \\
\hline \multirow[t]{2}{*}{ Mother college degree } & -0.047 & 0.013 \\
\hline & $(0.093)$ & $(0.091)$ \\
\hline \multirow[t]{2}{*}{ Mother education missing } & -0.112 & -0.072 \\
\hline & $(0.139)$ & $(0.133)$ \\
\hline \multirow[t]{2}{*}{ Number of computers in home } & -0.014 & -0.009 \\
\hline & $(0.025)$ & $(0.025)$ \\
\hline \multirow[t]{2}{*}{ Internet in home } & 0.016 & $0.105^{* *}$ \\
\hline & $(0.053)$ & $(0.051)$ \\
\hline \multirow[t]{2}{*}{ Attention issue } & 0.044 & -0.045 \\
\hline & $(0.086)$ & $(0.075)$ \\
\hline \multirow[t]{2}{*}{ Fall } & -0.080 & 0.174 \\
\hline & $(0.106)$ & $(0.106)$ \\
\hline \multirow[t]{2}{*}{ Winter } & 0.035 & $0.247^{* *}$ \\
\hline & $(0.103)$ & $(0.097)$ \\
\hline \multirow[t]{2}{*}{ Year 2002-2003 } & -0.111 & 0.061 \\
\hline & $(0.089)$ & (0.089) \\
\hline Number of observations & 391 & 332 \\
\hline \multicolumn{3}{|c|}{$\begin{array}{l}\text { Note: CDS child weights used. Standard errors clustered by household are in parentheses. } \\
\text { Regressions also include indicator variables for grade-level, single-mother household, other } \\
\text { family structure, and race. Significance levels: } * * * p<0.01 ; * * p<0.05 ;{ }^{*} p<0.10 \text {. }\end{array}$} \\
\hline
\end{tabular}




\begin{tabular}{|c|c|c|}
\hline Independent variables & Female & Male \\
\hline \multirow[t]{2}{*}{ WJ-R broad reading test score } & 0.003 & $0.004 *$ \\
\hline & $(0.002)$ & $(0.002)$ \\
\hline \multirow[t]{2}{*}{ WJ-R applied problems test score } & -0.002 & -0.004 \\
\hline & $(0.003)$ & $(0.003)$ \\
\hline \multirow[t]{2}{*}{ Test score missing } & $-0.235^{* * *}$ & -0.070 \\
\hline & $(0.086)$ & $(0.102)$ \\
\hline \multirow[t]{2}{*}{ Private school } & 0.062 & 0.109 \\
\hline & $(0.097)$ & $(0.107)$ \\
\hline \multirow[t]{2}{*}{ Midwest } & 0.049 & 0.086 \\
\hline & $(0.099)$ & $(0.095)$ \\
\hline \multirow[t]{2}{*}{ South } & 0.107 & 0.078 \\
\hline & $(0.100)$ & $(0.100)$ \\
\hline \multirow[t]{2}{*}{ West } & $0.182 *$ & $0.210^{* *}$ \\
\hline & $(0.100)$ & $(0.087)$ \\
\hline \multirow[t]{2}{*}{ Number of household children under age 20} & 0.011 & $-0.052^{*}$ \\
\hline & $(0.029)$ & $(0.031)$ \\
\hline \multirow[t]{2}{*}{ Household income } & -0.000 & 0.000 \\
\hline & $(0.001)$ & $(0.001)$ \\
\hline \multirow[t]{2}{*}{ Household income squared } & 0.000 & -0.000 \\
\hline & $(0.000)$ & $(0.000)$ \\
\hline \multirow[t]{2}{*}{ Mother college degree } & 0.115 & $0.191 * *$ \\
\hline & $(0.077)$ & $(0.076)$ \\
\hline \multirow[t]{2}{*}{ Mother education missing } & -0.040 & 0.135 \\
\hline & $(0.106)$ & $(0.146)$ \\
\hline \multirow[t]{2}{*}{ Number of computers in home } & 0.013 & -0.017 \\
\hline & $(0.024)$ & $(0.026)$ \\
\hline \multirow[t]{2}{*}{ Internet in home } & -0.010 & 0.021 \\
\hline & $(0.051)$ & $(0.062)$ \\
\hline \multirow[t]{2}{*}{ Attention issue } & $0.229 * * *$ & 0.050 \\
\hline & $(0.085)$ & $(0.080)$ \\
\hline \multirow[t]{2}{*}{ Fall } & -0.055 & 0.031 \\
\hline & $(0.088)$ & $(0.114)$ \\
\hline \multirow[t]{2}{*}{ Winter } & 0.071 & 0.048 \\
\hline & $(0.082)$ & $(0.115)$ \\
\hline \multirow[t]{2}{*}{ Year 2002-2003 } & $0.167 *$ & -0.138 \\
\hline & $(0.087)$ & $(0.085)$ \\
\hline Number of observations & 411 & 343 \\
\hline \multicolumn{3}{|c|}{$\begin{array}{l}\text { Note: CDS child weights used. Standard errors clustered by household are in parentheses. } \\
\text { Regressions also include indicator variables for grade-level, single-mother household, other } \\
\text { family structure, and race. Significance levels: }{ }^{* * *} \mathrm{p}<0.01 ;{ }^{* *} \mathrm{p}<0.05 ;{ }^{*} \mathrm{p}<0.10 \text {. }\end{array}$} \\
\hline
\end{tabular}


Appendix Table A1. Elementary School Sample Selection

\begin{tabular}{lc}
\hline & $\begin{array}{c}\text { Number of } \\
\text { Observations }\end{array}$ \\
\hline Attend elementary school in 1997 and/or 2002-2003 & 2,224 \\
Drop those who did not complete both a weekday and weekend day diary & 1,976 \\
$\begin{array}{l}\text { Drop those interviewed during winter break and in June when they do not } \\
\text { attend school on diary day }\end{array}$ & 1,896 \\
Drop if missing race & 1,892 \\
Drop if missing family structure & 1,874 \\
Drop if family income is negative & 1,873 \\
\hline Elementary School Analysis Sample & $\mathbf{1 , 8 7 3}$ \\
Females & $\mathbf{8 9 6}$ \\
Males & $\mathbf{9 7 7}$ \\
\hline
\end{tabular}


Appendix Table A2. Middle School Sample Selection

Number of

Observations

Attend middle school in 2002-2003 or 2007-2008

1,287

Drop those who did not complete both a weekday and weekend day diary

1,123

Drop those interviewed during winter break and in June when they do not $\quad 1,034$ attend school on diary day

Drop those missing child interview in 2007

1,026

Drop if missing race

1,025

Drop if missing family structure

1,017

Middle School Analysis Sample

1,017

Females

531

Males

486 
Appendix Table A3. High School Sample Selection

Number of

Observations

Attend high school in 2002-2003 or 2007-2008

1,648

Drop those who did not complete both a weekday and weekend day diary

1,429

Drop those interviewed during winter break and in June when they do not

1,287 attend school on diary day

Drop those missing child interview in 2007

1,270

Drop if missing race

1,266

Drop if missing family structure

1,250

Drop if family income is negative

1,249

High School Analysis Sample

1,249

Females

628

Males

621 
Appendix Table A4. Proportion of Students in Each Grade Level by Survey Year

\begin{tabular}{|l|c|c|}
\hline Grade Level & Year = 1997-1998 & Year = 2002-2003 \\
\hline 1 & 0.19 & 0.21 \\
\hline 2 & 0.22 & 0.20 \\
\hline 3 & 0.18 & 0.19 \\
\hline 4 & 0.21 & 0.22 \\
\hline 5 & 0.20 & 0.20 \\
\hline & Year = 2002-2003 & Year = 2007-2008 \\
\hline 6 & 0.34 & 0.33 \\
\hline 7 & 0.35 & 0.34 \\
\hline 8 & 0.31 & 0.34 \\
\hline 9 & 0.28 & 0.29 \\
\hline 10 & 0.27 & 0.23 \\
\hline 11 & 0.22 & 0.23 \\
\hline 12 & 0.23 & 0.25 \\
\hline
\end{tabular}

